\title{
JAK2 V617F prevalence in Brazilian patients with polycythemia vera, idiopathic myelofibrosis and essential thrombocythemia
}

\author{
Bárbara da Costa Reis Monte-Mór, Anderson Ferreira da Cunha, Kátia Bórgia Barbosa Pagnano, \\ Sara Terezinha Saad, Irene Lorand-Metze and Fernando Ferreira Costa \\ Centro de Hematologia e Hemoterapia, Faculdade de Ciências Médicas, \\ Universidade Estadual de Campinas, Campinas, SP, Brasil
}

\begin{abstract}
Polycythemia vera (PV), essential thrombocythemia (ET) and idiopathic myelofibrosis (IMF) are myeloproliferative disorders (MPD) that arise from the clonal proliferation of a pluripotent hematopoietic progenitor, leading to the overproduction of one or more myeloid lineages. Recently, a specific mutation in the JAK2 gene, which encodes a tyrosine kinase, has been shown to be associated with the myeloproliferative phenotype observed in PV, ET and IMF. In this study of Brazilian patients, the JAK2 V617F mutation [c.1887G > T) was detected in four out of 49 patients with PV (96\%), 14 out of 25 patients with IMF (56\%), and in eight out of 29 patients with ET, which is in accordance with previous screenings of this mutation in other populations.
\end{abstract}

Key words: JAK2 V617F, myeloproliferative disorders, polycythemia vera, idiopathic myelofibrosis, essential thrombocythemia.

Received: July 14, 2006; Accepted: November 26, 2006.

Polycythemia vera (PV), essential thrombocythemia (ET), idiopathic myelofibrosis (IMF) and chronic myelocytic leukemia (CML) are myeloproliferative disorders (MPD) that have been shown to arise clonally from a pluripotent hematopoietic stem cell (Fialkow et al., 1967; Adamson et al., 1976; Jacobson et al., 1978; Fialkow et al., 1981). Important manifestations of these disorders are bone marrow hypercellularity and pan-myeloid myeloproliferation, leading to overproduction of one or more hematopoietic lineages (Spivak et al., 2003). In addition, constant hallmarks of MPD bone marrow cells are their hypersensitivity to several cytokines (Prchal and Axelrad, 1974; Dai et al., 1992; Correa et al., 1994; Dai et al., 1994) and their ability to generate EPO-independent erythroid colonies in vitro (Prchal and Axelrad, 1974), commonly referred to as endogenous erythroid colonies (EECs). Recently, gene JAK2, which encodes a tyrosine kinase required for effective signaling in response to several cytokines (Parganas et al. 1998), was found mutated in these conditions. A somatic mutation, c.1887G > T (p.Val617Phe), ref. sequence NM_004972, commonly known as JAK2 V617F, has been described in the majority of patients with PV and in a subset of patients with ET and IMF (Baxter et al., 2005; James et al., 2005; Kralovics et al., 2005; Levine et al., 2005; Zhao et

Send correspondence to Fernando F. Costa. Rua Carlos Chagas 480, Barão Geraldo, 13083-97 Campinas, SP, Brazil. E-mail: ferreira@unicamp.br. al., 2005). It is noteworthy that among the growth factors to which MPD hematopoeitic progenitors are hypersensitive, EPO, SCF, GM-CSF, IL3, TPO and IGF-1 use JAK2 for signaling (Kaushansky, 2005). It has been demonstrated that the valine-to-phenylalanine substitution at amino acid position 617 leads to constitutive tyrosine phosphorylation activity and promotes cytokine hypersensitivity (James et al., 2005; Kralovics et al., 2005; Levine et al., 2005; Zhao et al., 2005). Moreover, EEC colonies cloned from PV patients were all shown to carry the mutation (Baxter et al., 2005), and lethally-irradiated mice transplanted with JAK2 V617Fexpressing bone marrow developed substantial erythrocytosis (James et al. , 2005). These observations indicate that this mutation contributes to the myeloproliferative phenotype, a finding with direct implications in the establishment of diagnosis protocols and the patient management (Campbell and Green, 2005). Establishing the prevalence of this mutation in patients with PV, ET and IMF is of practical importance. This prompted us to carry out what is, to our knowledge, the first screening of the JAK2 V617F mutation in Brazilian patients with PV, ET and IMF.

Peripheral blood samples were obtained from 49 patients with PV, 25 patients with IMF, and 29 patients with ET, seen at the Haematology and Haemotherapy Centre (UNICAMP, Brazil), from July through December, 2005. The diagnoses of PV, IMF and ET were made according to the World Health Organization (WHO) criteria, based on peripheral blood counts and bone marrow histology. Pe- 
ripheral blood samples from eight healthy volunteers were used as controls, since no healthy individuals have been shown to harbor the $J A K 2 \mathrm{~V} 617 \mathrm{~F}$ mutation (Baxter et al., 2005; James et al., 2005; Kralovics et al., 2005; Levine et al., 2005; Zhao et al., 2005). The study protocol was approved by the local ethics committee, and informed consent was obtained from all patients. Genomic DNA was extracted using the GFX Genomic Blood DNA Purification Kit (Amersham-Life Science). The presence of the JAK2 V617F mutation was assessed as previously described (Baxter et al., 2005). JAK2 amplicons were obtained using primers $J A K 2$ forward (5'-GGGTTTCCTCAGAACGTT GA-3') and JAK2 reverse (5'-TCATTGCTTTCCTTTTT CACAA-3'). PCR amplifications were performed in $50 \mu \mathrm{L}$ reaction mixes containing 50-100 ng of genomic DNA, $0.2 \mathrm{mM}$ dNTP's, $2 \mathrm{mM} \mathrm{MgCl}_{2}, 0.2 \mathrm{pmol}$ of each primer, 1X PCR buffer, and $1 \mathrm{U}$ Taq DNA polymerase. The cycling parameters were as follows: $96{ }^{\circ} \mathrm{C}$ for 2 min followed by 45 cycles at $96{ }^{\circ} \mathrm{C}$ for $30 \mathrm{~s}, 57^{\circ} \mathrm{C}$ for $30 \mathrm{~s}$, and $72{ }^{\circ} \mathrm{C}$ for $1 \mathrm{~min}$. The $460 \mathrm{bp}$ PCR product (Figure 1A) was submitted to $B s a$ XI (New England BioLabs inc.) digestion, for $16 \mathrm{~h}$ at $37{ }^{\circ} \mathrm{C}$, and analyzed on a $2 \%$ agarose gel. The JAK2 wild-type allele yields $241 \mathrm{bp}, 189 \mathrm{bp}$ and $30 \mathrm{bp} \mathrm{Bsa}$ XI fragments, while the JAK2 V617F allele remains undigested, since the mutation causes loss of the enzyme site. The Bsa XI digestion pattern in $J A K 2$ V617F-negative patients and healthy controls is shown in Figure 1B, lanes 1 and 4. Patients who are positive for the mutation have both the undigested $460 \mathrm{bp}$ fragment, corresponding to the $J A K 2$ V617F allele, and the $B s a$ XI fragments of the JAK2 wild-type allele (Figure 1B, lanes 2 and 3). The intensity of the digested fragments visualized on the agarose gel varies from patient to patient, due to differences in the homozygous or heterozygous status of the mutation and in the proportion of clonal cells in the total population. This appears to be a time- and cost-effective methodology for the detection of the $J A K 2 \mathrm{~V} 617 \mathrm{~F}$ mutation.

Among the 49 patients with PV studied, the JAK2 V617F mutation was detected in 47 (96\%). Among the patients with IMF, 14 out of $25(56 \%)$ had the mutation, while eight $(28 \%)$ of the 29 ET patients were positive. These frequencies are in agreement with those previously reported (Table 1).

There are already studies in the literature on the contribution of the $J A K 2$ mutation to clinical status and disease

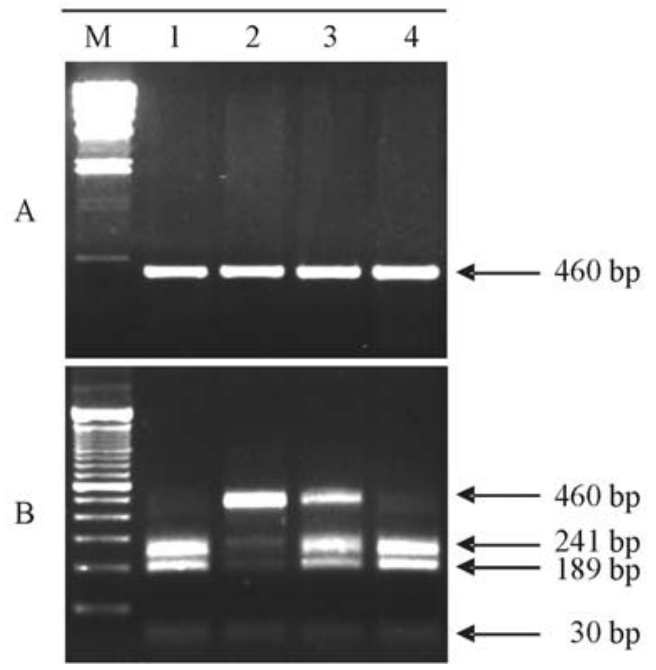

Figure 1 - JAK2 V617F screening by PCR and Bsa XI digestion. Lanes 1-3: Patients with (1) essential thrombocythemia, ET; (2) polycythemia vera, PV; (3) idiopathic myelofibrosis, IMF. Lane 4: Control individual. (A) 460 bp undigested PCR product; lane M, $\lambda$-Hind III fragments (New England BioLabs Inc.); (B) Bsa XI digestion of the 460 bp PCR product yields $241 \mathrm{bp}, 189 \mathrm{bp}$ and $30 \mathrm{bp}$ fragments from the wild-type allele; the fragment corresponding to the $J A K 2 \mathrm{~V} 617 \mathrm{~F}$ mutation remains undigested: normal alleles in a patient with ET (1); a normal and a mutated allele in patients with PV (2) and IMF (3); normal alleles in a control individual (4). Lane M, 100 bp molecular weight ladder (New England BioLabs Inc.).

severity. A prospective study suggests that two ET subtypes can be defined according to the $J A K 2$ genotype, and that ET patients carrying the $J A K 2 \mathrm{~V} 617 \mathrm{~F}$ mutation have phenotypic similarities with PV patients (Campbell et al., 2005). A multicentric study of IMF patients demonstrated that there is no correlation between many of the clinical features and the presence of the JAK2 V617F mutation, but, interestingly, JAK2 V617F-positive patients had a decreased survival (Campbell et al., 2006). It has been shown that, while most of the clinical characteristics of PV did not differ between JAK2 V617F homozygous and heterozygous patients, the former had higher hemoglobin levels at the time of diagnosis, increased incidence of pruritus, higher rates of fibrotic transformation, and higher PRV-1 transcript levels in granulocytes (Tefferi et al., 2006).

The discovery of this mutation has direct implications in the establishment of diagnosis protocols and in the management of patients (Campbell and Green, 2005), and has a great potential for the classification of MPDs and for the development of target therapy (Vainchenker and

Table 1 - Frequencies of the $J A K 2$ V617F mutation in Brazilian patients and in patients from the literature presenting with polycythemia vera, idiopathic myelofibrosis and essential thrombocythemia.

\begin{tabular}{|c|c|c|c|c|c|c|}
\hline Myeloproliferative disorders & This study & $\begin{array}{c}\text { Baxter } \\
\text { et al. }(2005)\end{array}$ & $\begin{array}{c}\text { James } \\
\text { et al. }(2005)\end{array}$ & $\begin{array}{l}\text { Kralovics } \\
\text { et al. }(2005)\end{array}$ & $\begin{array}{c}\text { Levine } \\
\text { et al. }(2005)\end{array}$ & $\begin{array}{c}\text { Zhao } \\
\text { et al. }(2005)\end{array}$ \\
\hline Polycythemia vera & $47 / 49(96 \%)$ & $71 / 73(97 \%)$ & $40 / 45(89 \%)$ & $83 / 128(65 \%)$ & $121 / 164(74 \%)$ & $20 / 24(84 \%)$ \\
\hline Idiopathic myelofibrosis & $14 / 25(56 \%)$ & $8 / 16(50 \%)$ & $3 / 7 \quad(43 \%)$ & $13 / 23(57 \%)$ & $16 / 46 \quad(35 \%)$ & - \\
\hline Essential thrombocythemia & $8 / 29(28 \%)$ & $29 / 51(57 \%)$ & $9 / 21(43 \%)$ & $21 / 93(23 \%)$ & $37 / 115(33 \%)$ & - \\
\hline
\end{tabular}


Constantinescu, 2005). JAK2 genotyping of patients with PV, IMF and ET is likely to become a clinically useful assay, and sensitive, effective techniques for the routine detection of $J A K 2 \mathrm{~V} 617 \mathrm{~F}$ are being developed and tested (James et al., 2006; McClure et al., 2006). Among the questions to be addressed in the investigation of the molecular pathogenesis of MPDs is how a single mutation can give rise to three phenotypically different diseases.

\section{Acknowledgments}

This study was supported by grants from FAPESP and CAPES.

\section{References}

Adamson JW, Fialkow PJ, Murphy S, Prchal JF and Steinmann L (1976) Polycythemia vera: Stem-cell and probable clonal origin of the disease. N Engl J Med 295:913-916.

Baxter EJ, Scott LM, Campbell PJ, East C, Fourouclas N, Swanton S, Vassiliou GS, Bench AJ, Boyd EM, Curtin N, Scott MA, Erber WN and Green AR (2005) Acquired mutation of the tyrosine kinase JAK2 in human myeloproliferative disorders. Lancet 365:1054-1061.

Campbell PJ and Green AR (2005) Management of polycythemia vera and essential thrombocythemia. Hematology (Am Soc Hematol Educ Program): 201-208.

Campbell PJ, Griesshammer M, Dohner K, Dohner H, Kusec R, Hasselbalch HC, Larsen TS, Pallisgaard N, Giraudier S, Le Bousse-Kerdiles MC, Desterke C, Guerton B, Dupriez B, Bordessoule D, Fenaux P, Kiladjian JJ, Viallard JF, Briere J, Harrison CN, Green AR and Reilly JT (2006) V617F mutation in JAK2 is associated with poorer survival in idiopathic myelofibrosis. Blood 107:2098-2100.

Campbell PJ, Scott LM, Buck G, Wheatley K, East CL, Marsden JT, Duffy A, Boyd EM, Bench AJ, Scott MA, Vassiliou GS, Milligan DW, Smith SR, Erber WN, Bareford D, Wilkins BS, Reilly JT, Harrison CN and Green AR (2005) Definition of subtypes of essential thrombocythaemia and relation to polycythaemia vera based on JAK2 V617F mutation status: A prospective study. Lancet 366:1945-1953.

Correa PN, Eskinazi D and Axelrad AA (1994) Circulating erythroid progenitors in polycythemia vera are hypersensitive to insulin-like growth factor-1 in vitro: Studies in an improved serum-free medium. Blood 83:99-112.

Dai CH, Krantz SB, Dessypris EN, Means Jr. RT, Horn ST and Gilbert HS (1992) Polycythemia vera. II. Hypersensitivity of bone marrow erythroid, granulocyte-macrophage, and megakaryocyte progenitor cells to interleukin-3 and granulocyte-macrophage colony-stimulating factor. Blood 80:891-899.

Dai CH, Krantz SB, Green WF and Gilbert HS (1994) Polycythaemia vera. III. Burst-forming units-erythroid (BFU-E) response to stem cell factor and c-kit receptor expression. Br J Haematol 86:12-21.

Fialkow PJ, Faguet GB, Jacobson RJ, Vaidya K and Murphy S (1981) Evidence that essential thrombocythemia is a clonal disorder with origin in a multipotent stem cell. Blood 58:916-919.
Fialkow PJ, Gartler SM and Yoshida A (1967) Clonal origin of chronic myelocytic leukemia in man. Proc Natl Acad Sci USA 58:1468-1471.

Jacobson RJ, Salo A and Fialkow PJ (1978) Agnogenic myeloid metaplasia: A clonal proliferation of hematopoietic stem cells with secondary myelofibrosis. Blood 51:189-194.

James C, Delhommeau F, Marzac C, Teyssandier I, Couedic JP, Giraudier S, Roy L, Saulnier P, Lacroix L, Maury S, Tulliez M, Vainchenker W, Ugo V and Casadevall N (2006) Detection of JAK2 V617F as a first intention diagnostic test for erythrocytosis. Leukemia 20:350-353.

James C, Ugo V, Le Couedic JP, Staerk J, Delhommeau F, Lacout C, Garcon L, Raslova H, Berger R, Bennaceur-Griscelli A, Villeval JL, Constantinescu SN, Casadevall N and Vainchenker W (2005) A unique clonal JAK2 mutation leading to constitutive signalling causes polycythaemia vera. Nature 434:1144-1148.

Kaushansky K (2005) On the molecular origins of the chronic myeloproliferative disorders: It all makes sense. Blood 105:4187-4190.

Kralovics R, Passamonti F, Buser AS, Teo SS, Tiedt R, Passweg JR, Tichelli A, Cazzola M and Skoda RC (2005) A gain-offunction mutation of JAK2 in myeloproliferative disorders. N Engl J Med 352:1779-1790.

Levine RL, Wadleigh M, Cools J, Ebert BL, Wernig G, Huntly BJ, Boggon TJ, Wlodarska I, Clark JJ, Moore S, Adelsperger J, Koo S, Lee JC, Gabriel S, Mercher T, D'Andrea A, Frohling S, Dohner K, Marynen P, Vandenberghe P, Mesa RA, Tefferi A, Griffin JD, Eck MJ, Sellers WR, Meyerson M, Golub TR, Lee SJ and Gilliland DG (2005) Activating mutation in the tyrosine kinase JAK2 in polycythemia vera, essential thrombocythemia, and myeloid metaplasia with myelofibrosis. Cancer Cell 7:387-397.

McClure R, Mai M and Lasho T (2006) Validation of two clinically useful assays for evaluation of JAK2 V617F mutation in chronic myeloproliferative disorders. Leukemia 20:168-171.

Parganas E, Wang D, Stravopodis D, Topham DJ, Marine JC, Teglund S, Vanin EF, Bodner S, Colamonici OR, van Deursen JM, Grosveld G and Ihle JN (1998) Jak2 is essential for signaling through a variety of cytokine receptors. Cell 93:385-395

Prchal JF and Axelrad AA (1974) Letter: Bone-marrow responses in polycythemia vera. N Engl J Med 290:1382.

Spivak JL, Barosi G, Tognoni G, Barbui T, Finazzi G, Marchioli R and Marchetti M (2003) Chronic myeloproliferative disorders. Hematology (Am Soc Hematol Educ Program): 200224.

Tefferi A, Lasho TL, Schwager SM, Strand JS, Elliott M, Mesa R, Li CY, Wadleigh M, Lee SJ and Gilliland DG (2006) The clinical phenotype of wild-type, heterozygous, and homozygous JAK2V617F in polycythemia vera. Cancer 106:631635.

Vainchenker W and Constantinescu SN (2005) A unique activating mutation in JAK2 (V617F) is at the origin of polycythemia vera and allows a new classification of Myeloproliferative diseases. Hematology (Am Soc Hematol Educ Program): 195-200.

Zhao R, Xing S, Li Z, Fu X, Li Q, Krantz SB and Zhao ZJ (2005) Identification of an Acquired JAK2 Mutation in Polycythemia Vera. J Biol Chem 280:22788-22792.

Associate Editor: Peter L. Pearson 